\title{
Seasonal Changes in Herding Behavior \\ Patterns and Interanimal Relationship \\ of Holstein Heifers in a
}

Common Pasture

KiyOShi HAYASAKA

Hokkaido National Agricultual Experiment Station, Sapporo-shi 004

(Received December 25, 1986)

\begin{abstract}
Changes in herding and individual behavior of a herd of dairy heifers in a common pasture were observed twice or 3 times a month from mid-May to mid-October. The herd consisted of 50 to 90 Holstein heifers from different farms or owners, of which about a quarter had been grazed in this pasture the previous year (second-year heifers). They were rotated between 6 hilly paddocks. Observation data were grouped into 3 periods : the early, middle and late periods of the grazing season. In the early period of the grazing season, heifers, except several solitary ones, formed several subgroups mainly composed of companions from the same farm in different sites of a paddock. Solitary heifers were located on the periphery of these subgroups. In the middle period of the grazing season, the herd gathered together in a small area. The period coincided with that of the activity of large-sized horse flies such as Tabanus chrysurus, which attacked individuals located around the periphery of the herd. As a result, second-year heifers, having fine physique, were located around the center of the herd. In the late period of the grazing season, the herd dispersed extending over a wide area. Throughout the grazing season, relationships between individuals also varied with the lapse of time: the percentage of the cases where the nearest neighbor of each animal was an individual from the same farm tended to decrease gradually. This suggested that the close bonds within each original group from the different farms gradually loosened and changed into new bonds which were formed in the present herd.
\end{abstract}

Jpn. J. Zootech. Sci., 58 (8):687-697, 1987

Key words : grazing cattle, common pasture, behavior

Dairy heifers are not directly involved in milk production activities. Therefore, in common pastures, dairy heifers brought together from different farms are grazed as a herd from spring to fall every year for the purpose of labor-saving production.

The behavior of dairy cattle in an extensive common pasture over a long period has been previously investigated ${ }^{1-4}$ ), but the reports do not show clear descriptions of whether or not observations were done in a common pasture. Moreover, by revealing the history of each individual in advance before grazing, changes in herding behavior and interanimal relationships in a herd of one kind, consisting of different histories, have hardly, if ever, been studied. Understanding these changes is useful for effective 


\section{HAYASAKA}

grazing management practices for a herd of cattle.

The objectives of this study are as follows : (1) to clarify seasonal changes in patterns of herding behavior and in associations between individual members within a herd in a common pasture, and (2) to determine various factors influencing their changes.

\section{Materials and Methods}

Observations were made at the Hachirougahara Common Pasture, Shiobara, Tochigi. This pasture which had been divided into 6 hilly paddocks as of 1980 , is located at 800 to $950 \mathrm{~m}$ altitude above sea-level (Fig. 1). The 6 paddocks had areas from 5 to 18 ha, totaling 66.7 ha. Every paddock was artificial grassland chiefly grassed with orchard grass (Dactylis glomerata L.) except that half of the 4 th paddock was native grassland with bamboo grass (Sasa kurilensis).

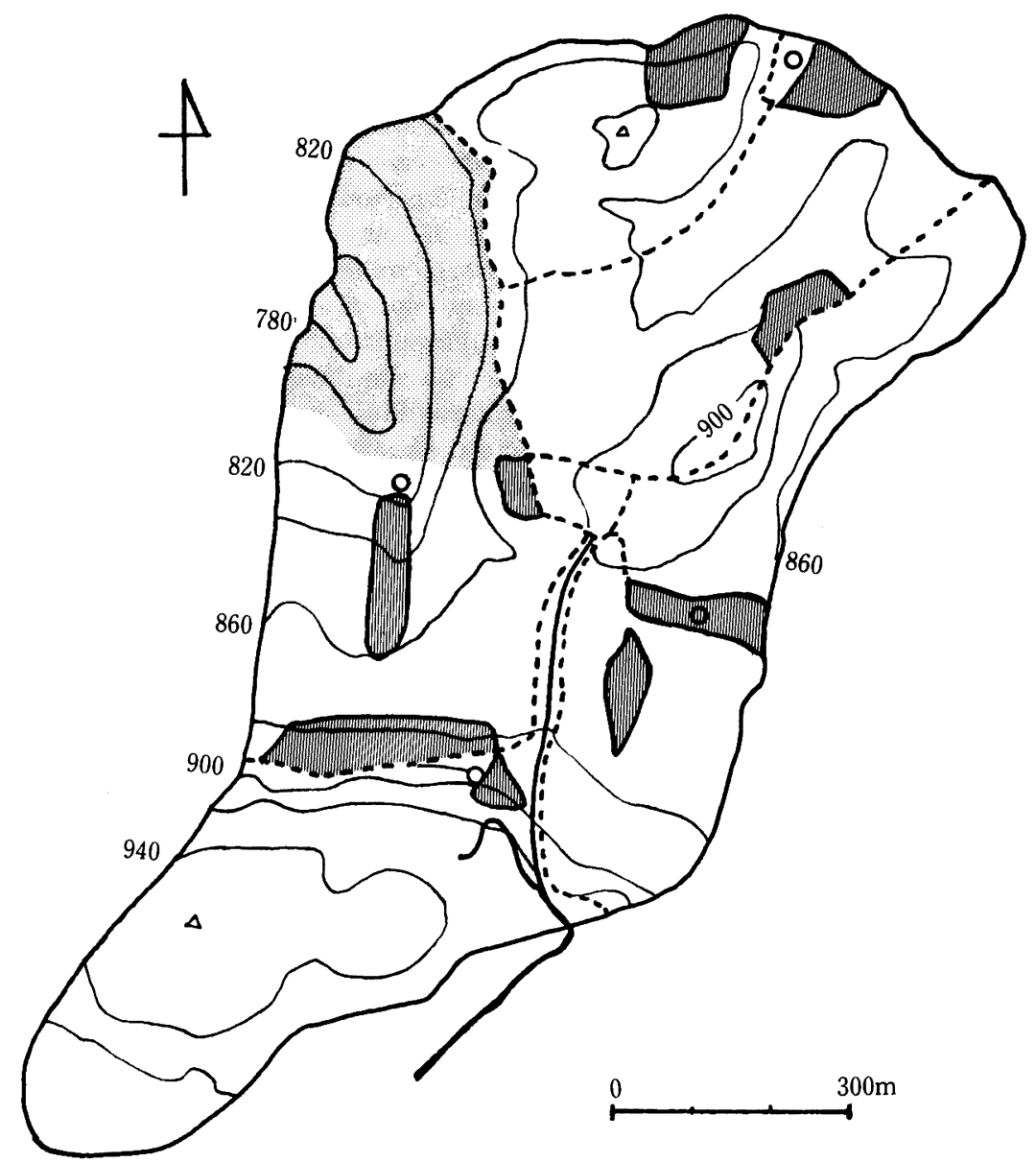

Fig. 1. Topography of the Hachirogahara Pasture

$\square$ : artificial pasture $\Gamma$ : natural pasture

III: shade $\bigcirc$ : water trough ---- : fence 
Holstein heifers from different farms were grouped into 2 herds before the beginning of grazing : one group was more than $250 \mathrm{~kg}$ or so and the other under $250 \mathrm{~kg}$ in body weight. Each heifer was marked with a number on each flank for identification and its body weight was measured. Also, the date of birth and owner's name were

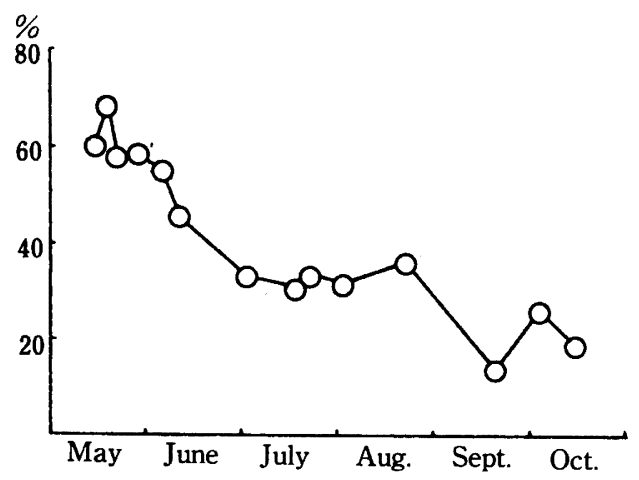

Fig. 2. Seasonal changes in percentage of the cases where the nearest neighbor of each animal is individual born and reared in the same farm
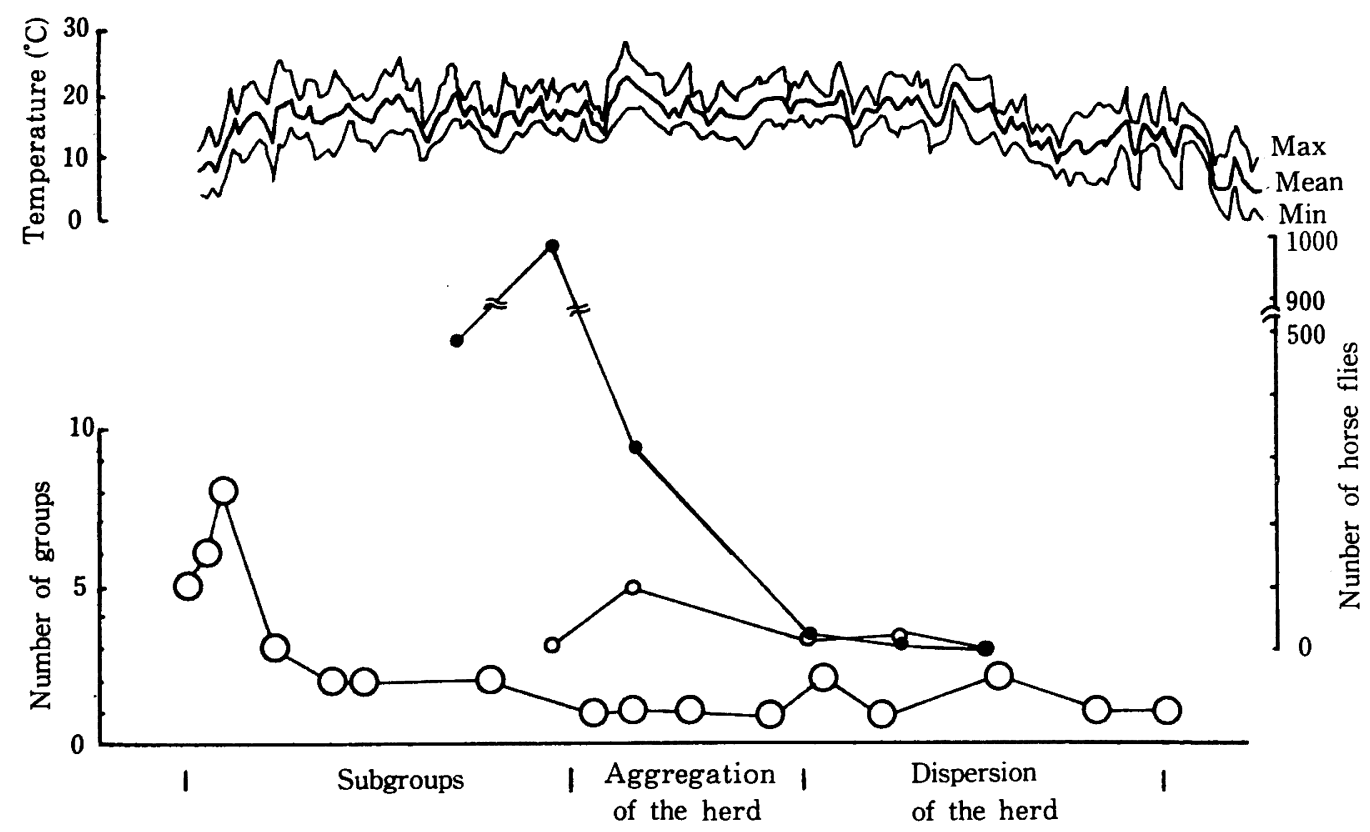

1 May 1 June 1 July 1 Aug. 1 Sept. 1 Oct. 1

Fig. 3. Seasonal changes in the number groups as of $10: 00$ a. m. $(-\bigcirc-)$, the number of horse flies $^{1)}\left(-O^{-}: T\right.$. chrysurus, $-\bullet: T$. nipponicus) and temperature ${ }^{2)}$ 1) collected with $\mathrm{CO}_{2}-$ baited trap by MATSUMURA 2) measured by the Environmental Hygiene Lab (Kankyoueiseiken), Natl Grassl. Res. Inst. 


\section{HAYASAKA}

investigated in advance.

Thereafter, the 2 herds were continuously grazed separately without supplementary feed from mid-May to mid-October, with occasional rotation between the 6 paddocks. This paper discusses the herd composed of individuals of more than $250 \mathrm{~kg}$ or so in body weight, but the average number of members was 50 in mid-May, $65 \pm 3$ from late May to mid-July and $82 \pm 8$ from late July to mid-October mainly because bettergrowing heifers within the herd under $250 \mathrm{~kg}$ were on occasion transferred to the herd under observation, or because cattle were newly introduced shortly after the beginning

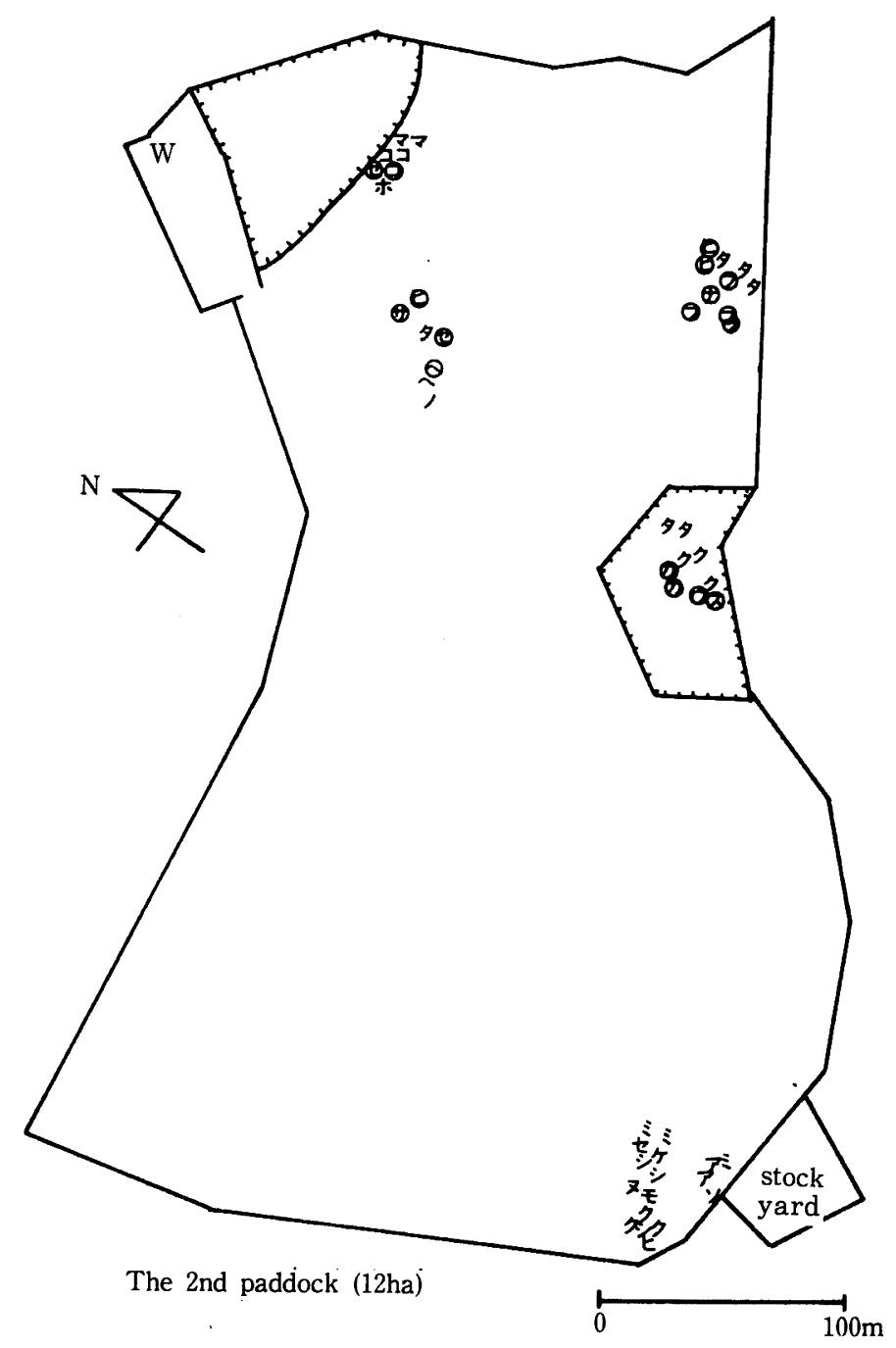

Fig. 4. A typical example of location records in the early grazing period (May 14, 1980) - The katakana denotes the location of individual and the symbol for the farm where the individual was born. - The $\bigcirc$ around katakana denotes individual grazed in this pasture on the previous year. W: water trough 


\section{The Behavior of Grazing Cattle}

of the grazing season. About three quarters of the observation herd had not had any grazing experience in this pasture while the other quarter had been grazed there the previous year. The inexperienced heifers, 8 to 18 months in age, are referred to as first-year heifers and the experienced heifers, 18 to 31 months in age, as second-year heifers in this paper. The number of heifers which each owner put in this pasture ranged from 1 to 7 .

Observations were made between $10: 00 \mathrm{a} . \mathrm{m}$. and $4: 00 \mathrm{p.m}$. on 14 days of fine or cloudy weather during the 5-month grazing period : the individual locations, at around $10: 00$ a.m. when cattle were usually lying or standing, were plotted on a field map and the behavior was observed attentively until $4: 00$ p.m. every time.

Since large-sized horse flies seemed to have an effect on interanimal relationship, further observations to clarify the relationship between the two were also made the next summer.

\section{Results}

The spatial pattern of the herd of Holstein heifers in the paddocks changed with time. At the same time, the relationships between individual members within the herd also varied : the percentage of the cases where the nearest neighbor of each animal was an individual born and bred in the same farm was as high as 60 to $68 \%$ in May and decreased to about $20 \%$ with lapse of time (Fig. 2). From characteristic changes in herding behavior and relationships between individuals, observations were grouped into 3 periods.

\section{Early grazing period}

The about 2 months from mid-May to mid-July. The temperature averaged 15.5 ${ }^{\circ} \mathrm{C}$. The herd was divided into 2 to 8 subgroups in different locations of a paddock, especially evident during the first week after the beginning of grazing (Figs. 3 and 4). Each subgroup was, in many cases, out of visual contact with the other subgroups because of rolling hill paddocks. All the heifers, except solitary ones, preferred the company of heifers from the same farm. In particular, the association between individuals grazed as a pair from the same farm (paired heifers) was much stronger than that between individuals grazed as 3 or more heifers from the same farm. Moreover, second-year heifers tended to have close bonds with one another (Fig. 4). Several solitary heifers without a companion from farms were outstanding as an individualists for the first week from the beginning of grazing, in that they were located on the periphery of subgroups or at a distance from subgroups with uneasy attitude and were grazing intermittently when others were lying down. Agonistic behavior between individuals to determine dominance order were seldom, if ever, found, although they were partly found in the stockyard before grazing.

In this period, each subgroup was composed of several basic social units of which each consisted of individuals from the same farm. These social units moved between subgroups because associations between these social units were loose, and consequently the composition of subgroups changed frequently. 


\section{Middle grazing period}

The 1 month period in mid-July and mid-August, when the temperature averaged $17.8^{\circ} \mathrm{C}$. Individual members aggregated as shown in Fig. 5. The aggregation period of individuals coincided with that of activity of large-sized horse flies such as Tabanus chrysurus attacking grazing heifers (Fig. 3). The association between individuals was loose as compared with that of the early period. Agonistic behavior between individuals such as buttings or flank attacks was seen frequently because of the aggregation of individuals in a small area. Second-year heifers, having fine physique, were aggressive to occupy the center of the herd where the activity of horse flies was laxer (Fig. 5).

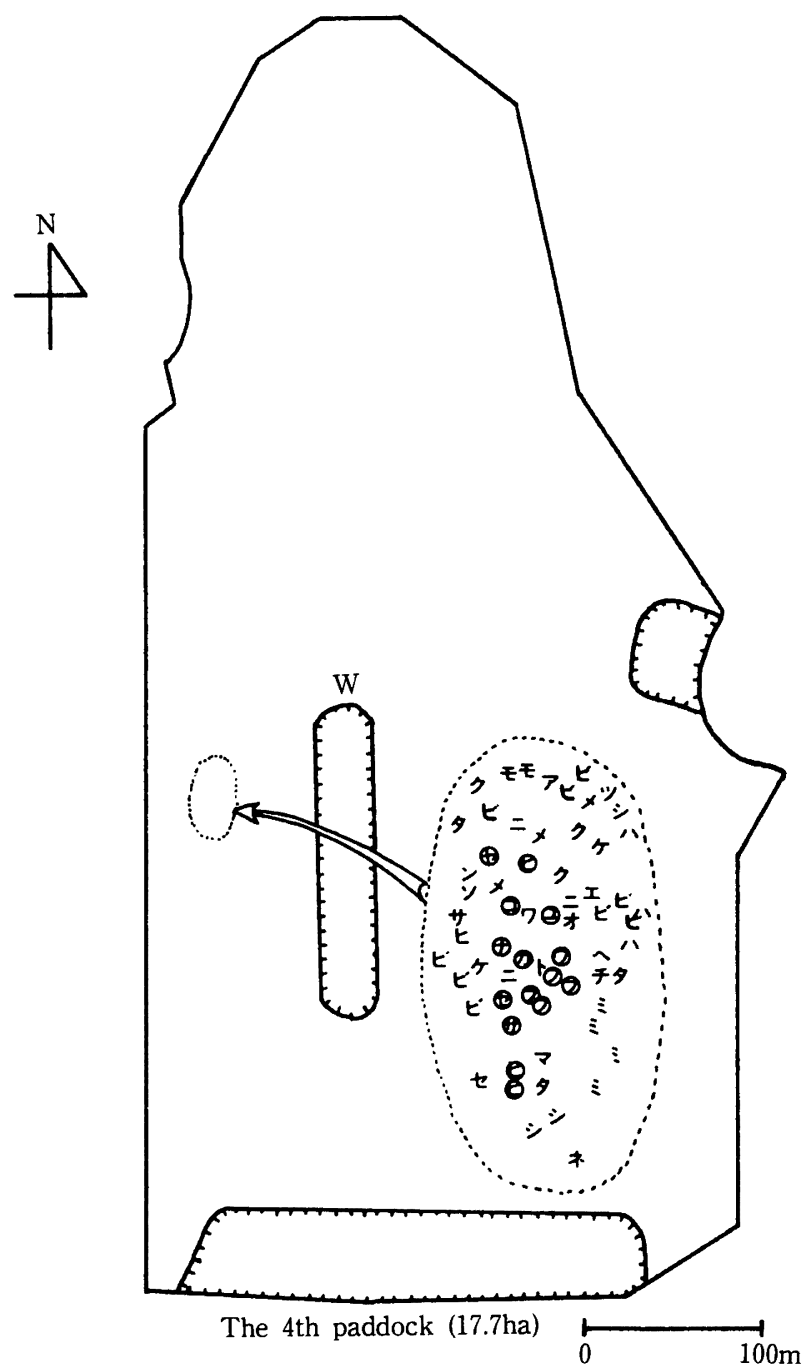

Fig. 5. A typical example of location records in the middle grazing period (July 21, 1980) - The symbol is the same as in Fig. 4 Fad : shade W: water trough 


\section{The Behavior of Grazing Cattle}

Similar results were confirmed by the next summer's survey (Fig. 6). In addition, white heifers with black markings were not more attacked by horse flies than black ones with white markings.

\section{Late grazing period}

The about 2 month period from late August to mid-October, when the temperature averaged $14.7{ }^{\circ} \mathrm{C}$. Extending over a wide area, the herd dispersed as shown in Fig. 7 . The association between individuals in this period was looser than in any other.

\section{Discussion}

SATo et $a l^{5-7)}$ reported that changes in the spatial pattern of a herd of cattle were influenced by a variety of factors such as grazing season, the area of pasture, the vegetation of pasture, appetite level and the appearance of biting flies. This will be true for herds which consist of members born and bred in the same farm or herd. However, spatial patterns in a herd composed of different histories vary not only by changes in those factors but also by association between individual members ${ }^{8,9}$.

In the early grazing period, the herd was divided into several subgroups. Cattle

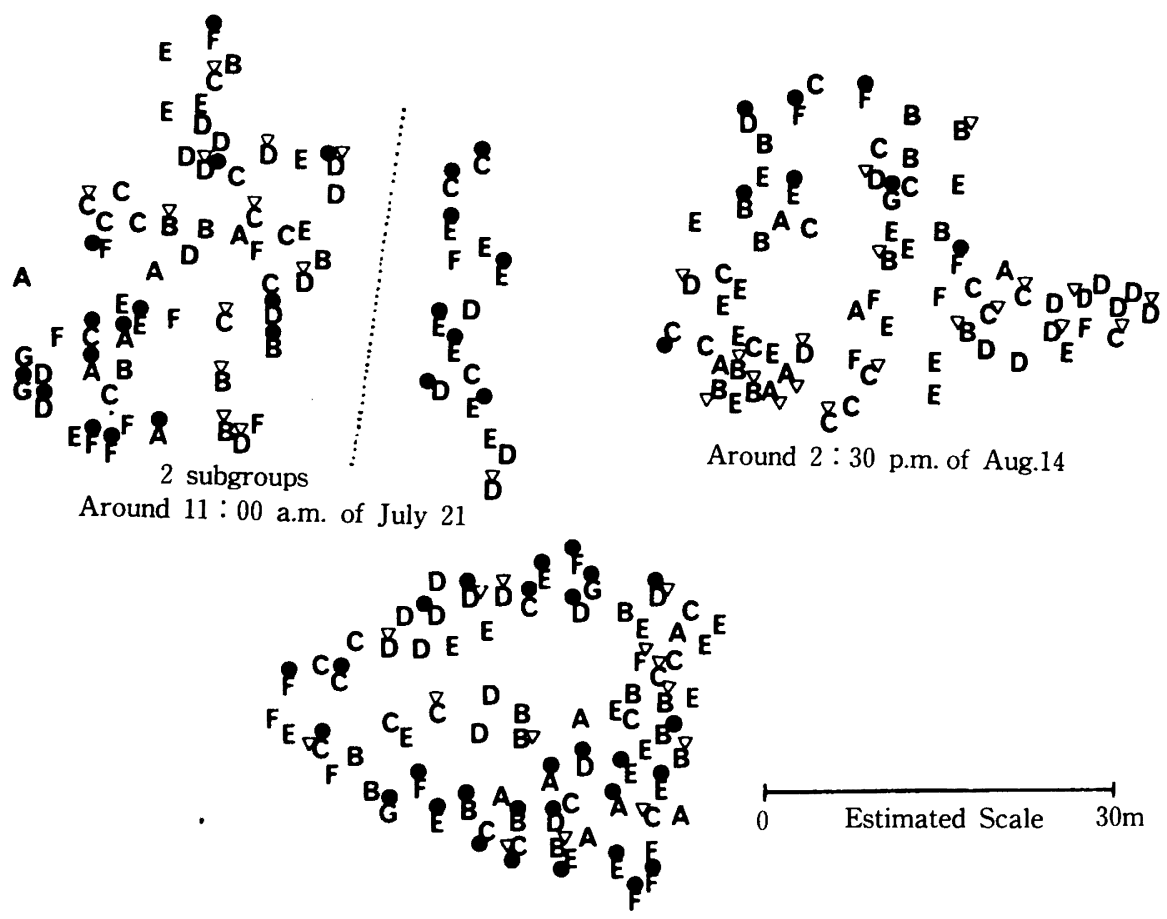

Around $1: 40$ p.m. of July 30

Fig. 6. Spatial distribution of cattle under conditions attacked by large-sized horse flies such as $T$. chrysurus in the summer of 1981 - The alphabet denotes the location of individual and the symbol for its body weight shown as follows. $A \geqq 400(\mathrm{~kg})>B \geqq 350>C \geqq 300>D \geqq 250>$ $\mathrm{E} \geqq 200>\mathrm{F} \geqq 150>\mathrm{G}$. The $\bullet$ on an alphabet denotes the individual attacked by 1 to 3 largesized horse flies. - The $\nabla$ on an alphabet denotes the rather white heifer with black spots. 


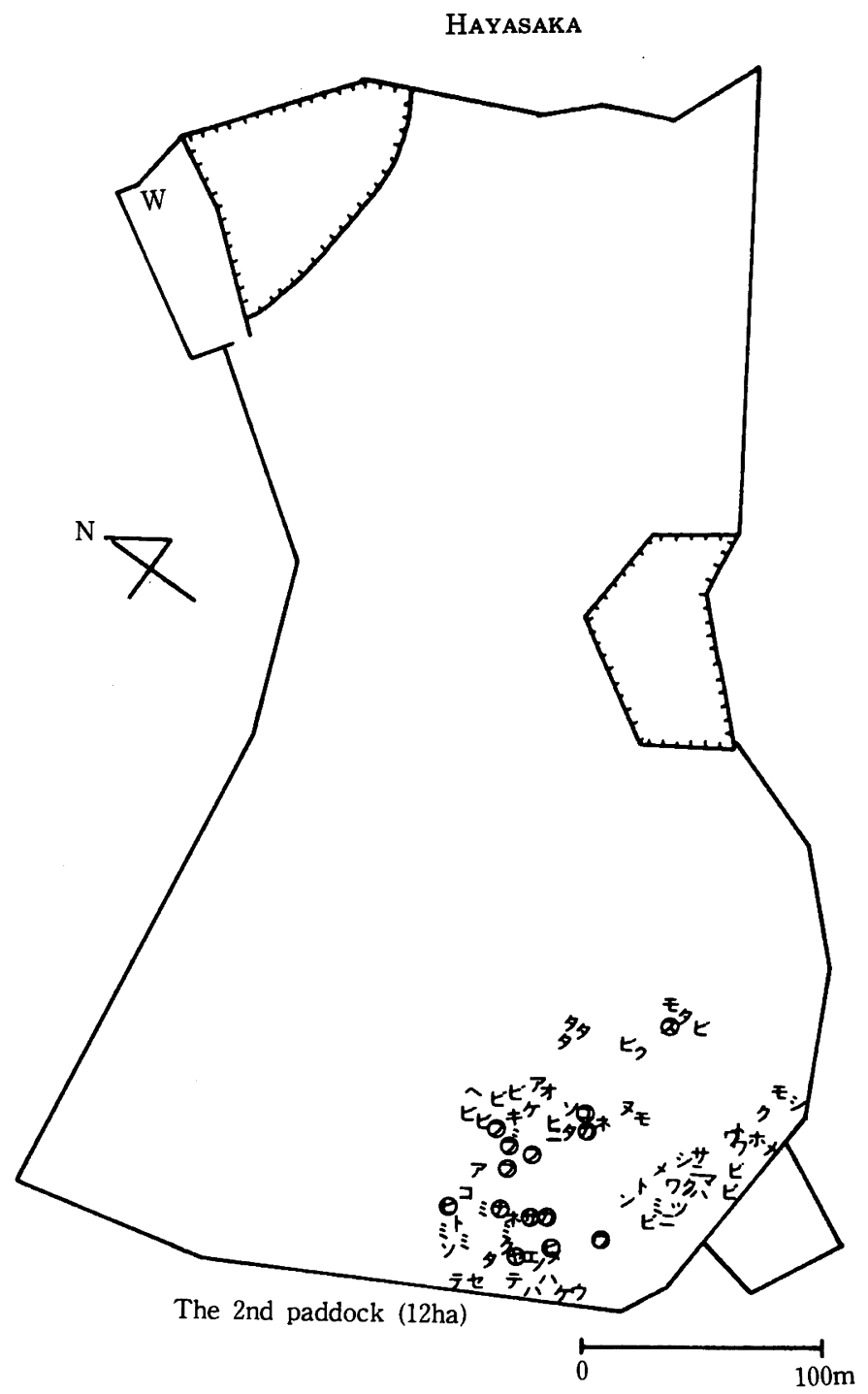

Fig. 7. A typical example of location records in the late grazing period (Oct. 14, 1980) The symbol is the same as in Fig. 4 : shade $\mathrm{W}$ : water trough

usually behave more or less as a herd, not as an individual, but the spatial pattern in this period means that each individual has a strong tendency to associate more closely with the other companions from the same farm than with any individuals within the herd. It was often observed, for example, that paired heifers moved away from subgroups and behaved as pairs freely. Similar observations have been reported by several authors ${ }^{1,4,10}$. This observations, that the herd of a single breed is divided into several subgroups, agrees with the statement of ARNOLD and $\mathrm{PAHL}^{11)}$ that, in a lower stocking rate and larger paddock of 16 ha, 2 groups of 100 sheep grazed as separate groups in different areas of the paddock or with the findings of SuzukI et al. ${ }^{12)}$ in cattle. 
In the middle grazing period, individual members aggregated as a whole herd. This is not merely because the individuals tend to know each other by sight gradually but because the individuals behave to take refuge from attacks by large-sized horse flies. Several researchers ${ }^{5,7,13-15)}$ have given a similar interpretation that the aggregation of individual animals in summer is a self-defensive behavior as a herd against attacks of biting flies. On the other hand, according to Kondo et al. ${ }^{16,17)}$, another reason for the aggregation in summer is that cattle seek the shade and rest within it. However, it was unlikely in this case because cattle almost aggregated both within and without shady trees in the meantime.

The reason for which the stronger second-year heifers, in contrast to first-year heifers, tended to locate around the center of the herd, is possibly due to the fact that attacks by large-sized horse flies are more frequent on the periphery than around the center of the herd. Namely, the stronger animals can obtain the best place that horse flies do not attack, and the weaker animals are expelled from the place.

According to the $1980-81$ survey $^{18)}$ of dipterous pests in this pasture, among the 21 tabanid species captured, Tabanus nipponicus was $75 \%$ of the total and among 9 muscid species, Musca hervei was $98 \%$ of the total. However, defensive behavior against these dominant species was not particularly observed despite the observation ${ }^{19)}$ of fly-avoidance behavior against face flies (Musca autumnalis De Geer), which is similar in classification to Musca hervei.

ARNOLD and $\mathrm{PAHL}^{11)}$ described that it took approximately 3 weeks for 2 groups within the flock to become integrated. Kondo and Nishino ${ }^{20)}$, Kondo et al. ${ }^{21)}$ carried out a series of experiments to statistically clarify changes in spatial pattern after grouping, by putting calves of various group sizes in a small paddock, and found that it took several days to become stable. On the other hand, in the herd in observations, the aggregation or fusing of individual members have not completed for approximately 2 months since the beginning of grazing. The difference in time for aggregation or fusing is presumably due to the number of original groups contained in its herd or flock, species differences and the size of the paddocks grazed. For example, the herd utilized in this study consisted of over 20 original groups from different dairy farms, whereas the flock used by ARNOLD and $\mathrm{PAHL}^{11)}$ was made up of 2 original groups. Further, horse flies' attacks in summer that forced individual members to aggregate, may also become a distant cause of influencing time for aggregating.

In the late grazing period when the individual members dispersed, mixing was completed. This spatial pattern is apparently the stablest of these 3 periods and may be caused by the decrease in herbage quality and quantity in fall ${ }^{5,6,16,17)}$.

With the lapse of season, relationships between individuals in the herd seem to move into one direction: the close bonds within each original group from different farms break down, and new bonds are gradually formed between any individuals within the whole herd. 


\section{HAYASAKA}

\section{Acknowledgements}

The author is thankful to the staff of the Hokine Dairy Cooperative Association for permission to observe cattle grazed in the Hachirougahara Common Pasture, Tochigi and to Dr. M. ShIYom of the Natl Grassl. Res. Inst. for reviewing this manuscript. Information on changes in horse flies and temperature in this pasture was given by Dr. T. Matsumura and the Environmental Hygiene Lab., the Natl Grassl. Res. Inst.

\section{References}

1) Korzumi, T. and I. Hondo, The Journal of the Hokkaido Veterinary Medicine Association, $7:$ 145-151. 1963.

2) Ohno, W. and A. TanaKa, J. Japan. Grassl. Sci., $11: 132-137.1965$.

3) Ohno, W. and A. Tanaka, J. Japan. Grassl. Sci., $11:$ 138-143. 1965.

4) Ohno, W. and A. Tanaka, J. Japan. Grassl. Sci., $12: 37-41.1966$.

5) Sato, S., I. Ito and K. Hayashi, J. Japan. Grassl. Sci., 22 : 313-318. 1976.

6) Sato, S., I. Ito and K. Hayashi, J. Japan. Grassl. Sci., $23: 325-329.1978$.

7) Sato, S., I. Ito and K. Hayashi, J. Japan. Grassl. Sci., $23:$ 330-333. 1978.

8) Sato, S., T. Yamagishi and Y. Mizuma, J. Japan. Grassl. Sci., 22 : 307-312. 1976.

9) Hayasaka, K., Jpn. J. Zootech. Sci., $57: 992-999.1986$.

10) Ewbank, R., J. Dairy Sci., 50 : 1510-1512. 1967.

11) Arnold, G.W. and P.J. Pahl, Anim. Behav., 22 : 592-600. 1974.

12) Suzuki, S., H. Sawamura and S. Yamamoto, J. Japan. Grassl. Sci., 18 : 320-328. 1972.

13) Ito, I., J. Japan. Grassl. Sci., $17: 133-140.1971$.

14) Kurosaki, Z., H. Tamate and S. Inzumi, Bull. Inst. Agri. Res. Tohoku Univ., 10 : 213-223. 1958.

15) Matsumura, T., H. Hayakawa and T. Hasegawa, Misc Publ. Tohoku Natl. Agric. Exp. Stn., 1: 45-53. 1978.

16) Kondo, S., T. Nona, T, Ітон, Y. Asahida and Y. Hirose, Res. Bull. Livestock Farm, Fac. Agr. Hokkaido Univ., 8 : 93-109. 1977.

17) Kondo, S., T. Nona, Y. Asahida and Y. Hirose, Res. Bull. Livestock Farm, Fac. Agr. Hokkaido Univ., 9: 1-13. 1979.

18) Matsumura, T. and Y. Ito, Bull. Natl Grassl. Res. Inst., $30: 60-70.1985$.

19) Schmidtmann E.T. and M.E. Valla, Appl. Anim. Ethol., $8: 429-438.1982$.

20) Kondo, S. and S. Nishino, Proc. 5th WCAP, $2: 815-816.1983$.

21) Kondo, S. N. Kawakami, H. Kohama and S. Nishino, Appl. Anim. Ethol., 11 : $217-$ 228. 1984. 


\title{
公共牧場のホルスタイン種育成牛群における 集団形成之個体間関係の季節的変化
}

\author{
早坂 貴代史
}

農林水産省北海道農業試験場，札幌市 004

放牧牛群の生態は種々の条件によって変化するが，公 共牧場の牛群は互いに認知していない個体同士で構成さ れている場合が多いために，その群生態は社会的条件が 大きく関与してくるものと考えられる. そこで杤木県塩 原町八郎ヶ原牧場のホル種育成・未経産牛群 50-90 頭を 対象に，群生態および個体間関係について 5 月中旬から 10 月中旬までの放牧期間中随時, 14 日間にわたり調查 した.

その結果, 放牧前期（5月中旬から 7 月中旬）では, 牛群はいくつかのサブグループにわかれて散在した. 個 体間関係では, 同一農家からの仲間牛同士, さらに前年
度放牧経験牛同士が集結して行動する傾向にあった，中 期（7月中旬から 8 月中旬）では，個体は一群に収束し， 体格の大きい未経産牛が群の中心部に位置した。この時 期はアカウシアブ (Tabanus chrysurus) などの大型 アブの活動時期と一致し, 群外縁部にその寄生が認めら れたことから一群集結は大型アブに対する防衛反応と考 えられ. 群の中心部はアブの攻撃の少ない好適な場と推 定された。 後期（8月下旬から10月中旬）では, 牛群 は広範囲に散開し，仲間牛同士集結する個体間開係が不 明確になった。

日畜会報, $58(8): 687-697,1987$ 